\title{
Seed viability test of orchids native to the Brazilian Savanna ${ }^{1}$
}

\author{
Jackeline Schultz Soares ${ }^{2}$, José Carlos Sorgato ${ }^{2}$,
} Luan Marlon Ribeiro², Jéssica Mônico Celeste Ramos²

\section{ABSTRACT}

An essential factor for the formation of a native orchid seed bank is the identification of the viability of stored seeds. This study aimed to determine a methodology for optimizing the tetrazolium test, in the identification of the viability of stored seeds of two Orchidaceae medicinal species native to the Brazilian Savanna. Seeds of Miltonia flavescens Lindl. and Schomburgkia crispa Lindl. were submitted to three pre-conditioning conditions: no soaking (control), sucrose solution or distilled water. The seeds were then submitted to a tetrazolium solution, with three types of conditioning: oven, water bath or ambient temperature. The M. flavescens seeds showed a germination of $86.91 \%$, with a higher percentage of viable seeds $(62.32 \%)$ when submitted to pre-conditioning with sucrose + oven conditioning. For $S$. crispa, the germination was $97.78 \%$, with a higher percentage of viable seeds for the control treatment + ambient temperature $(89.49 \%)$. These results suggest that specific protocols should be used to conduct the tetrazolium test in Orchidaceae. Moreover, when performed on a sample basis, the tetrazolium test should only be used to indicate the seed viability.

KEYWORDS: Miltonia flavescens Lindl., Schomburgkia crispa Lindl., Orchidaceae.

\section{INTRODUCTION}

Orchidaceae is one of the largest and most diverse families among angiosperms, second only to Compositae (Chase et al. 2015, The Plant List 2020). A total of 2,692 native orchid species are listed in the Flora do Brasil Project (Flora do Brasil 2021). These species are distributed in 251 genera, and 1,490 are endemic to the country. The Orchidaceae family is the third most representative of the plant biodiversity in the Brazilian Savanna biome (Batista et al. 2005,

\section{RESUMO}

Teste de viabilidade de sementes de orquídeas nativas do Cerrado brasileiro

Um fator essencial para a formação de um banco de sementes de orquídeas nativas é a identificação da viabilidade das sementes armazenadas. Objetivou-se determinar uma metodologia para a otimização do teste de tetrazólio, na identificação da viabilidade de sementes armazenadas de duas espécies medicinais de Orchidaceae nativas do Cerrado. Sementes de Miltonia flavescens Lindl. e Schomburgkia crispa Lindl. foram submetidas a três précondicionamentos: sem embebição (controle), solução de sacarose ou água destilada. Em seguida foram submetidas a solução de tetrazólio, com três tipos de condicionamento: estufa, banho maria ou temperatura ambiente. As sementes de $M$. flavescens apresentaram germinação de 86,91 \% e, quando submetidas ao pré-condicionamento com sacarose + condicionamento em estufa, mostraram maior porcentagem de sementes viáveis $(62,32 \%)$. Já para $S$. crispa, a germinação foi de $97,78 \%$ e observou-se maior porcentagem de sementes viáveis no tratamento controle + temperatura ambiente $(89,49 \%)$. Esses resultados sugerem que, em Orchidaceae, protocolos específicos devem ser utilizados na condução do teste de tetrazólio e, ainda, a realização do teste de maneira amostral deve ser utilizada apenas para a indicação da viabilidade das sementes.

PALAVRAS-CHAVE: Miltonia flavescens Lindl., Schomburgkia crispa Lindl., Orchidaceae.

Mendonça et al. 2008), showing species with little explored economic and ornamental potential. According to Flora do Brasil (2021), this biome accounts for 701 species, distributed in 126 genera.

Some orchid species are considered medicinal. According to Diazgranados et al. (2020), in the world checklist of useful plant species, 636 Orchidaceae species have medicinal use. Belloto et al. (2017) reported the isolation of a new natural product, called crispoic acid, from the epiphyte orchid Schomburgkia crispa Lindl., in addition to six other

\footnotetext{
${ }^{1}$ Received: Dec. 15, 2020. Accepted: Mar. 24, 2021. Published: Apr. 23, 2021. DOI: 10.1590/1983-40632021v5167069.

${ }^{1}$ Universidade Federal da Grande Dourados, Faculdade de Ciências Agrárias, Dourados, MS, Brasil.

E-mail/ORCID: jacke.schultz@gmail.com/0000-0001-9497-2975; josesorgato@ufgd.edu.br/0000-0003-0001-5467; luanmarlon@hotmail.com/0000-0002-7278-7696; jessica_monico13@hotmail.com/0000-0002-3987-6726.
} 
chemical compounds already known, which are effective against cancer in cells. For the epiphyte Miltonia flavescens Lindl., the presence of bioactive compounds with pharmacological properties was already reported, including antifungal and anticancer agents (Porte et al. 2014).

Thus, storing seeds of native species is an important tool to prevent the loss of genetic resources, ensuring the preservation of biodiversity of this highly threatened plant family. Ex situ plant conservation - mainly with the formation of seed banks, aiming at the maintenance of genetic variability - may contribute to the restoration of natural populations (Yang et al. 2017, Gale et al. 2018, Seaton et al. 2018).

An essential factor for the formation of a native orchid seed bank is the identification of the viability of stored seeds which can be used for propagation and conservation of the species, since this viability may be affected even under favorable conditions (Doria 2010, Hosomi et al. 2017, Mercado et al. 2020). Therefore, the use of fast tests such as tetrazolium is important, mainly to decision-making regarding the management of seed banks (Marcos Filho 2015).

The tetrazolium test is based on the detection of the activity of dehydrogenase enzymes, particularly the malic acid dehydrogenase. This dehydrogenase reduces the 2,3,5 triphenyl tetrazolium chloride salt in the seed living tissues which transfer hydrogen ions to the salt (Marcos Filho 2015). A reduction reaction occurs in living cells when the seed is immersed in a tetrazolium solution, resulting in the formation of a non-diffusible red compound known as triphenylformazan. Such color indicates the occurrence of respiratory activity in the mitochondria and, consequently, the viability of the tissue. Dead (non-viable) tissues do not react with the solution, preserving their natural color (França Neto et al. 1998).

Methodologies for the tetrazolium test in Orchidaceae seeds have been proposed in the literature (Hosomi et al. 2011, Hosomi et al. 2012, Hosomi et al. 2017, Macedo et al. 2014, Soares et al. 2014). However, changes in the seed pre-conditioning and conditioning procedures for the test may increase the seed efficiency, since these changes aim to improve the visualization of viable seeds (Salazar \& Gélvez 2015, Custódio et al. 2016, Seaton et al. 2018, Mercado et al. 2020). For Trichocentrum jonesianum
Rchb. f., soaking in distilled water for $24 \mathrm{~h}$ provides better results for visualizing the seed viability (Lallana \& Garcia 2013). Hosomi et al. (2017), evaluating the tetrazolium test on Cattleya labiata and $C$. tigrina seeds, report that pre-conditioning in a $10 \%$ glucose or $10 \%$ sucrose solution is more effective for visualizing viable seeds. Mercado et al. (2020) found that the use of deionized water improves the efficiency of the tetrazolium test on Epidendrum fimbriatum, E. microtum and E. elongatum seeds.

Thus, this study aimed to determine a methodology for optimizing the tetrazolium test in the identification of the viability of stored seeds of the Orchidaceae species M. flavescens and S. crispa, native to the Brazilian Savanna.

\section{MATERIAL AND METHODS}

The experiment was conducted at the Universidade Federal da Grande Dourados, in Dourados (Mato Grosso do Sul state, Brazil). Miltonia flavescens Lindl. and Schomburgkia crispa Lindl. seeds were obtained from manual pollination and mother plants with more than ten years old and were grown in a nursery covered by the overlap of two $50 \%$ shading screens (Figure 1). The average irradiance, temperature and relative humidity were, respectively, $235 \mu \mathrm{mol} \mathrm{m}{ }^{-2} \mathrm{~s}^{-1}, 22.6 \pm 5^{\circ} \mathrm{C}$ and $73.9 \pm 10 \%$. Closed capsules were collected eight months after the pollination. Their seeds were removed, homogenized, weighed and kept in a desiccator with silica gel for 15 days. After this period, the seeds of each species were separately packed in aluminum foil, stored in opaque polypropylene screw-capped vials containing silica gel, and refrigerated at $4 \pm 2{ }^{\circ} \mathrm{C}$ for up to 180 days.

A total of thirty-six $0.001 \mathrm{~g}$ samples of stored seeds of each species were weighed and placed in test tubes. Sets of twelve tubes $(10 \mathrm{~mL})$ were preconditioned with three soaking pre-treatments: no soaking (control); $3 \mathrm{~mL}$ of sucrose solution (10\%) for $24 \mathrm{~h}$; and $3 \mathrm{~mL}$ of distilled water for $24 \mathrm{~h}$.

After 24 hours of pre-conditioning, the seeds (excluding those from the control treatment) were washed with distilled water three times and submitted to a $3 \mathrm{~mL}$ aqueous solution of 2,3,5 triphenyl tetrazolium chloride $(0.5 \%)$ (Soares et al. 2014). They were then placed in the darkness for $24 \mathrm{~h}$ and each set of twelve tubes coming from the pre-conditioning treatments were divided into three conditioning treatments: oven $\left(40{ }^{\circ} \mathrm{C}\right)$; water bath 


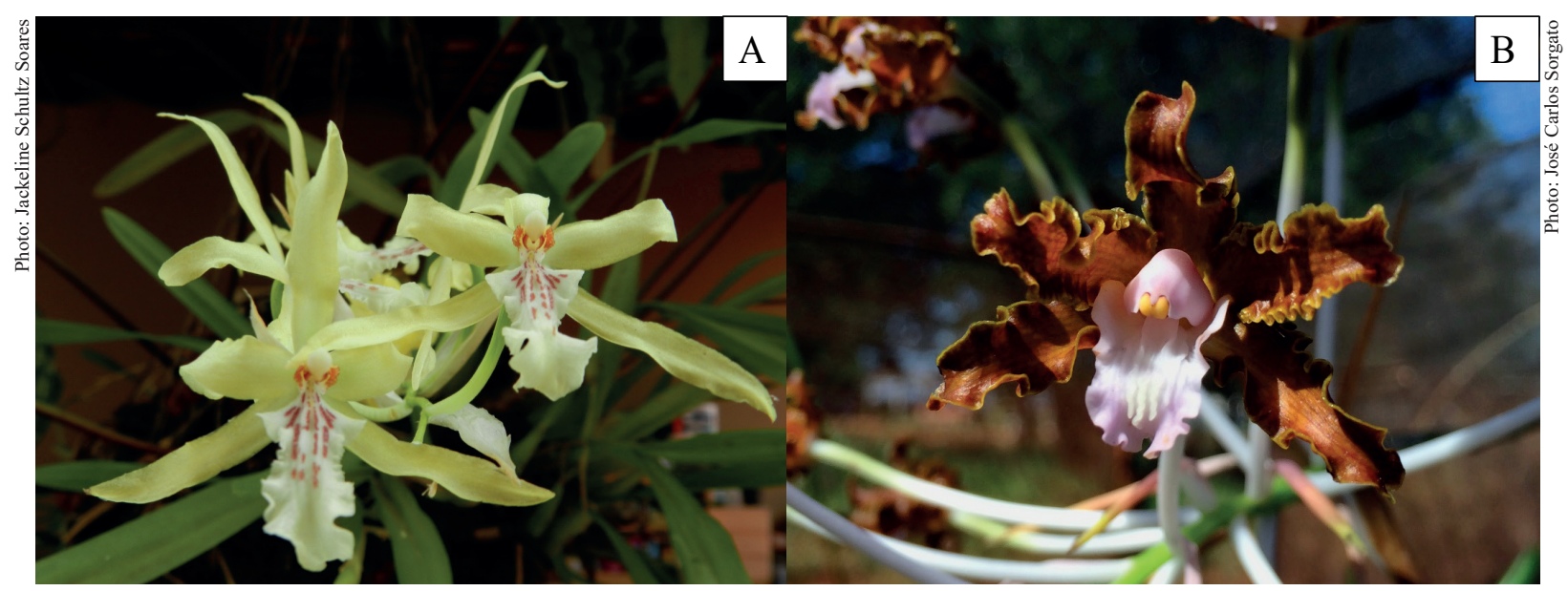

Figure 1. Mother plants of the orchid species Miltonia flavescens Lindl. (A) and Schomburgkia crispa Lindl. (B).

$\left(40{ }^{\circ} \mathrm{C}\right)$; and ambient temperature $\left(25 \pm 2{ }^{\circ} \mathrm{C}\right)$, with eight replicates of one tube each.

After 24 hours, $7 \mathrm{~mL}$ of distilled water were added to the $3 \mathrm{~mL}$ of tetrazolium solution in the tube and stirred to dilute the solution. Then, $1 \mathrm{~mL}$ was pipetted in a Peters chamber for identification and counting of viable seeds under a binocular stereoscopic zoom microscope. Seeds with totally carmine embryos, partially colored embryos and colorless embryos, as well as embryo-free seeds, were counted, the last three ones being considered non-viable seeds. From this counting, the percentage of viable seeds was determined using the following formula modified by Soares et al. (2014): (number of seeds with totally carmine embryos x 100)/total number observed seeds.

The treatments were photographed with a digital camera coupled to a stereoscopic microscope, using the AxionVision version 3.1 (Zeiss ${ }^{\mathrm{TM}}$ ) software. To confirm the results, immediately after the test, a sample of $0.005 \mathrm{~g}$ of seeds of each studied species (not subjected to tetrazolium) was taken to an aseptic environment and disinfected with $15 \mathrm{~mL}$ of a $0.8 \%$ sodium hypochlorite solution, remaining immersed for 5 min. Subsequently, the seed suspension was diluted to $50 \mathrm{~mL}$ and then washed three times with sterile distilled water $\left(121^{\circ} \mathrm{C}\right.$ and $1 \mathrm{~atm}$ pressure, for $20 \mathrm{~min}$ ). Then, the volume of the suspension was made up to $50 \mathrm{~mL}$ with sterile distilled water. For in vitro sowing, $1,000 \mu \mathrm{L}$ of seed suspension were inoculated per vial, with four culture vials for each species.

An amount of $60 \mathrm{~mL}$ of Murashige \& Skoog (1962) culture medium at half the normal salt concentration $(1 / 2 \mathrm{MS})$ was used per $600 \mathrm{~mL}$ vial (previously sterilized in an autoclave under $121{ }^{\circ} \mathrm{C}$ and $1 \mathrm{~atm}$ pressure, for $20 \mathrm{~min}$ ). Subsequently, the cultures were placed in a growth room with controlled temperature and photoperiod $\left(25 \pm 2{ }^{\circ} \mathrm{C} ; 16 \mathrm{~h}\right)$, and $22 \mu \mathrm{mol} \mathrm{m}{ }^{-2} \mathrm{~s}^{-1}$ of irradiance were provided by white fluorescent lamps.

The germination percentage was evaluated after 45 days of cultivation. For this purpose, $10 \mathrm{~mL}$ of distilled water were added to each culture vial. After manual shaking, the propagules suspension was poured into a Petri dish and the total number of seeds and the number of germinated seedlings were counted using a binocular stereoscopic zoom microscope. The germination percentage was calculated using the following formula (Rosa et al. 2013): (number of geminated seedlings $x$ 100)/total number of observed seeds.

A completely randomized design was used for each studied species, with the treatments arranged in a $3 \times 3$ factorial scheme (three pre-conditionings and three conditionings), with four replicates of one tube each. The experiment was performed in triplicate at the same time. The data were subjected to analysis of variance. When significant, the means of the treatments were compared by the Tukey test $(\mathrm{p}<0.05)$. The statistical analyses were conducted using the Sisvar v.5.3. software (Ferreira 2011).

\section{RESULTS AND DISCUSSION}

There was a combined effect $(p<0.05)$ of pre-conditioning and conditioning for the percentage 
of viable seeds in both species. For M. flavescens, the highest percentage of viable seeds was observed when the seeds were soaked in $3 \mathrm{~mL}$ of the sucrose solution (10\%) for $24 \mathrm{~h}$, and, subsequently, conditioned in an oven $\left(40{ }^{\circ} \mathrm{C}\right)(62.32 \%)$, although without statistical difference from those conditioned in ambient temperature $\left(25 \pm 2{ }^{\circ} \mathrm{C}\right)$ and water bath $\left(40{ }^{\circ} \mathrm{C}\right)$ (44.67 and $38.90 \%$, respectively) and pre-conditioned in $3 \mathrm{~mL}$ of distilled water for $24 \mathrm{~h}$ $(47.58 \%)$ (Table 1$)$.

For $S$. crispa, the highest percentage of viable seeds was observed for the control (no soaking) and, subsequently, for conditioning in ambient temperature $\left(25 \pm 2{ }^{\circ} \mathrm{C}\right)(89.49 \%)$, but there were no statistical differences between the pre-conditioning and conditioning in oven $\left(40^{\circ} \mathrm{C}\right)(74.62 \%)$ (Table 2$)$.

The results allowed to infer that the preconditioning of seeds before the test is a determinant factor for the increased visualization of M. flavescens and $S$. crispa viable seeds identified by the tetrazolium test.

The use of a $10 \%$ sucrose solution as preconditioning may increase the accuracy of the tetrazolium test (Hosomi et al. 2011, Hosomi et al. 2012, Hosomi et al. 2017, Custódio et al. 2016,
Seaton et al. 2018), since the soaking of seeds in this solution for $24 \mathrm{~h}$ favors the activation of the respiratory chain of enzymes in the embryo prior to the exposure to the tetrazolium solution (Seaton et al. 2018). When studying the pre-conditioning in Cattleya, Hosomi et al. (2012) observed favorable responses with the use of sucrose, which increased by $10 \%$ the number of viable seeds visualized in the tetrazolium test, when compared to the control.

Regardless of the pre-conditioning, there is an increase in the visualization of viable seeds of S. crispa when conditioned in ambient temperature $\left(25 \pm 2{ }^{\circ} \mathrm{C}\right)$. Hosomi et al. (2011 and 2012) reported that the sucrose pre-conditioning provides good viability results for Cattleya, while, for this species, the conventional tetrazolium test can be used (without prior seed soaking and with incubation at ambient temperature).

The difference in the viability results for both species (Figures 2 and 3 ) suggests that specific protocols should be used when conducting the tetrazolium test for a better visualization of viable orchid seeds (germination of $100 \%$ ).

The highest viability values found in the tetrazolium test were lower than those for germination

Table 1. Percentage of viable seeds of Miltonia flavescens Lindl., as a function of pre-conditioning and conditioning in the tetrazolium test.

\begin{tabular}{lccc}
\hline \multirow{2}{*}{ Pre-conditioning } & \multicolumn{3}{c}{ Viable seeds $(\%)$} \\
\cline { 2 - 4 } & Oven $\left(40{ }^{\circ} \mathrm{C}\right)$ & Water bath $\left(40{ }^{\circ} \mathrm{C}\right)$ & Ambient temperature $\left(25 \pm 2{ }^{\circ} \mathrm{C}\right)$ \\
\hline Control & $13.11 \mathrm{bC}^{*}$ & $41.54 \mathrm{aA}$ & $45.91 \mathrm{aA}$ \\
Sucrose $(3 \mathrm{~mL} ; 24 \mathrm{~h})$ & $62.32 \mathrm{aA}$ & $38.90 \mathrm{bA}$ & $44.67 \mathrm{bA}$ \\
Distilled water $(3 \mathrm{~mL} ; 24 \mathrm{~h})$ & $47.58 \mathrm{aB}$ & $43.82 \mathrm{aA}$ & $46.84 \mathrm{aA}$ \\
\hline Average & 41.00 & 41.42 & 45.81 \\
\hline CV $(\%)$ & 4.89 & & \\
\hline
\end{tabular}

* Means followed by the same lowercase letter in the row and uppercase letter in the column do not differ by the Tukey test $(\mathrm{p}<0.05)$.

Table 2. Percentage of viable seeds of Schomburgkia crispa Lindl., as a function of pre-conditioning and conditioning in the tetrazolium test.

\begin{tabular}{lccc}
\hline \multirow{2}{*}{ Pre-conditioning } & \multicolumn{3}{c}{ Viable seeds $(\%)$} \\
\cline { 2 - 4 } & Oven $\left(40{ }^{\circ} \mathrm{C}\right)$ & Water bath $\left(40^{\circ} \mathrm{C}\right)$ & Ambient temperature $\left(25 \pm 2{ }^{\circ} \mathrm{C}\right)$ \\
\hline Control & $2.94 \mathrm{bB}$ & $3.83 \mathrm{bC}$ & $83.93 \mathrm{aA}$ \\
Sucrose $(3 \mathrm{~mL} ; 24 \mathrm{~h})$ & $74.89 \mathrm{bA}$ & $86.43 \mathrm{aA}$ & $88.46 \mathrm{aA}$ \\
Distilled water $(3 \mathrm{~mL} ; 24 \mathrm{~h})$ & $74.62 \mathrm{bA}$ & $67.12 \mathrm{bB}$ & $89.49 \mathrm{aA}$ \\
\hline Average & 50.82 & 52.46 & 87.29 \\
\hline CV $(\%)$ & 3.51 & & \\
\hline
\end{tabular}

* Means followed by the same lowercase letter in the row and uppercase letter in the column do not differ by the Tukey test $(\mathrm{p}<0.05)$. 
C1
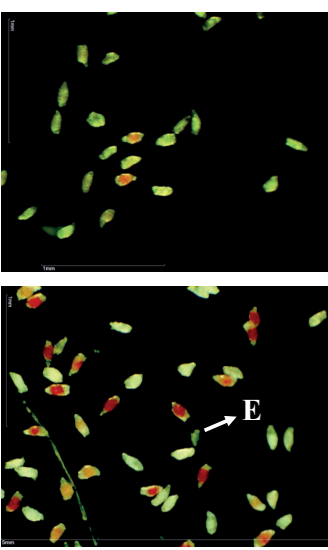

PC2

PC1

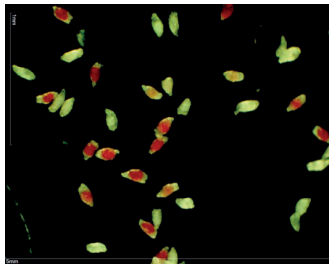

PC3
C2
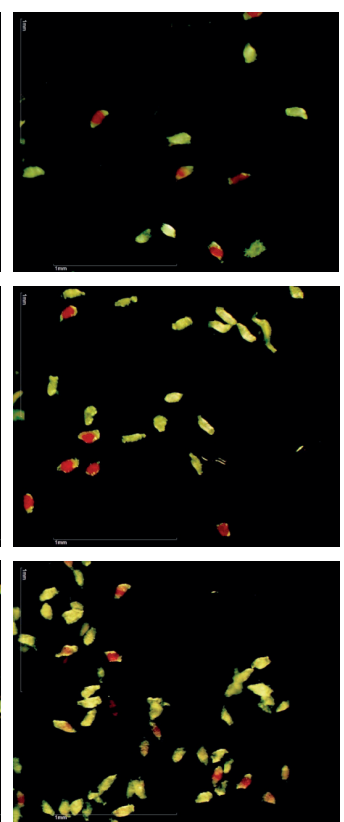

C3

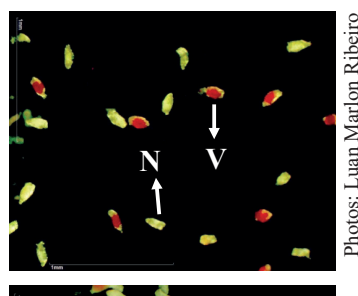

\section{$1 \mathrm{~mm}$}

Figure 2. Miltonia flavescens Lindl. seeds, as a function of pre-conditioning [PC1: no soaking (control); PC2: $3 \mathrm{~mL}$ of a $10 \%$ sucrose solution, for $24 \mathrm{~h}$; PC3: $3 \mathrm{~mL}$ of distilled water, for $24 \mathrm{~h}$ ] and conditioning [C1: oven $\left(40{ }^{\circ} \mathrm{C}\right)$; $\mathrm{C} 2$ : water bath $\left(40{ }^{\circ} \mathrm{C}\right)$; $\mathrm{C} 3$ : ambient temperature $\left.\left(25 \pm 2{ }^{\circ} \mathrm{C}\right)\right]$ in the tetrazolium test. $\mathrm{V}, \mathrm{N}$ and $\mathrm{E}$ : viable, non-viable and empty seed, respectively.

C1
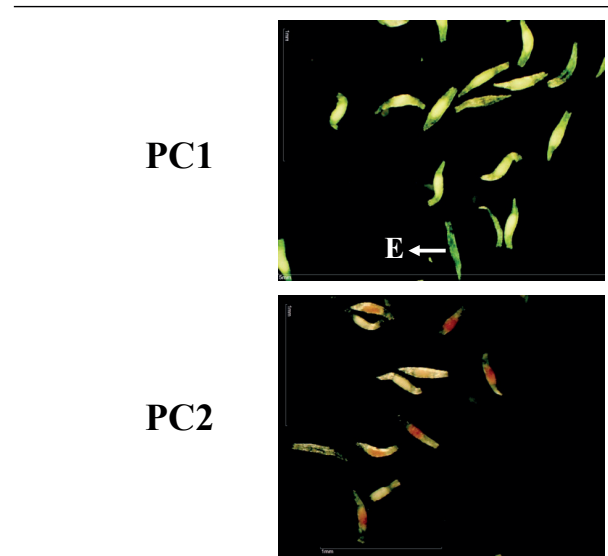

PC2

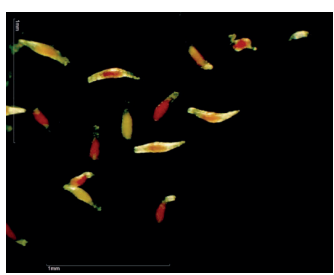

C2
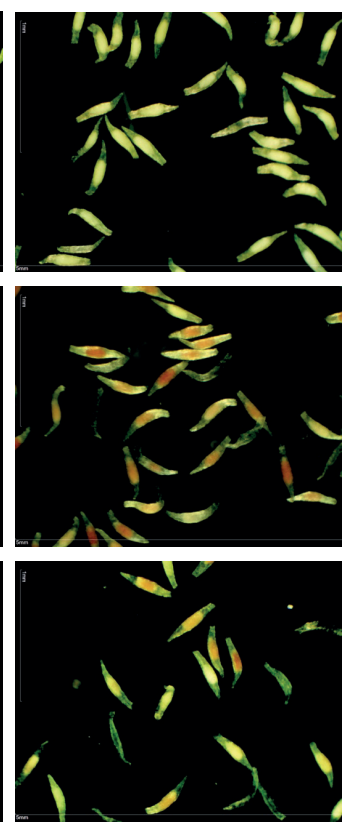

C3
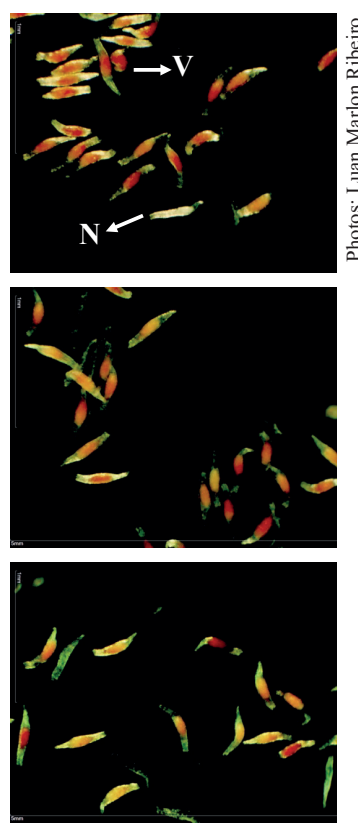

\section{$1 \mathrm{~mm}$}

Figure 3. Schomburgkia crispa Lindl. seeds, as a function of pre-conditioning [PC1: no soaking (control); PC2: $3 \mathrm{~mL}$ of a $10 \%$ sucrose solution, for $24 \mathrm{~h}$; PC3: $3 \mathrm{~mL}$ of distilled water, for $24 \mathrm{~h}]$ and conditioning $\left[\mathrm{C} 1\right.$ : oven $\left(40{ }^{\circ} \mathrm{C}\right) ; \mathrm{C} 2$ : water bath $\left(40^{\circ} \mathrm{C}\right)$; $\mathrm{C} 3$ : ambient temperature $\left.\left(25 \pm 2^{\circ} \mathrm{C}\right)\right]$ in the tetrazolium test. $\mathrm{V}, \mathrm{N}$ and $\mathrm{E}$ : viable, non-viable and empty seed, respectively. 
in the two studied species. M. flavescens showed a percentage of viable seeds of $62.32 \%$ and germination of $86.91 \%$, while $S$. crispa presented a percentage of viable seeds of $89.49 \%$ and germination of $97.78 \%$, at 45 days after sowing.

The number of potentially viable seeds observed in the tetrazolium test often may not correspond to the number of germinated seeds. When studying the viability of Brassavola tuberculata Hook. seeds, Rosa et al. (2013) reported a low correlation of the tetrazolium test results with the germination percentage, inferring that the sample method of this test can only be used to predict seed viability and not the likely germination percentage. These results refer to the mode of action of the test, which reflects the activity of the dehydrogenase enzymes involved in the respiration process, making it possible to distinguish the living parts of the seeds from the dead ones, which do not change color (Oliveira et al. 2005). The rules for seed analysis (Brasil 2009) recommend that partially colored embryos may or may not be viable, since the position and size of necrotic areas is what determines the seed viability.

Furthermore, orchid seeds are small, around $0.05 \mathrm{~mm}$ (Arditti \& Ghani 2000), what makes it difficult to perform cuts allowing a full visualization of the interior of the embryo for the proper assessment of damage to its essential tissues. Thus, seeds that were considered unfeasible in the tetrazolium test may have germinated under appropriate conditions, and seeds that were considered viable may not have germinated.

\section{CONCLUSIONS}

1. The difference in the results of percentage of viable seeds observed in Miltonia flavescens and Schomburgkia crispa suggests that specific methodologies should be used when conducting the tetrazolium test for a better visualization of viable orchid seeds;

2. Performed on a sample basis, the tetrazolium test may only be used to indicate the viability of stored seeds, and not the species germination potential.

\section{REFERENCES}

ARDITTI, J.; GHANI, A. K. A. Numerical and physical properties of orchid seeds and their biological implications. New Phytologist, v. 145, n. 3, p. 367-421, 2000.
BATISTA, J. A. N.; BIANCHETTI, L. B.; PELLIZZARO, K. F. Orchidaceae da Reserva Ecológica do Guará, DF, Brasil. Acta Botanica Brasilica, v. 19, n. 2, p. 221-232, 2005.

BELloto, C. A.; SOUZA, G. K.; PERIN, P. C.; SCHUQUEL, I. T. A.; SANTIN, S. M. O.; CHIAVELLI, L. U. R.; GARCIA, F. P.; KAPLUM, V.; RODRIGUES, J. H. S.; SCARIOT, D. B.; DELVECCHI, R.; MACHADOFERREIRA, E.; AGUIAR, R. S.; SOARES, C. A. G.; NAKAMURA, C. V.; POMINI, A. M. Crispoic acid, a new compound from Laelia marginata (Orchidaceae), and biological evaluations against parasites, human cancer cell lines and Zika virus. Natural Product Research, v. 31, n. 24, p. 2916-2921, 2017.

BRASIL. Ministério da Agricultura, Pecuária e Abastecimento. Regras para análise de sementes. 2009. Available at: https://www.abrates.org.br/files/regras analise_de_sementes.pdf. Access on: 05 Apr. 2020.

CHASE, M. W.; CAMERON, K. M.; FREUDENSTEIN, J. V.; PRIDGEON, A. M.; SALAZAR, G.; BERG, C. V. D.; SCHUITEMAN, A. An updated classification of Orchidaceae. Botanical Journal of the Linnean Society, v. 177, n. 2, p. 151-174, 2015.

CUSTÓDIO, C. C.; MARKS, T. R.; PRITCHARD, H. W.; HOSOMI, S. T.; MACHADO-NETO, N. B. Improved tetrazolium viability testing in orchid seeds with a thick carapace (Dactylorhiza fuchsii) or dark seed coat (Vanda curvifolia). Seed Science and Technology, v. 44, n. 1, p. 177-188, 2016.

DIAZGRANADOS, M.; ALLKIN, B.; BLACK, N.; CÁMARA-LERET, R.; CANTEIRO, C.; CARRETERO, J.; EASTWOOD, R.; HARGREAVES, S.; HUDSON, A.; MILIKEN, W.; NESBITT, W.; ONDO, I.; PATMORE, K.; PIRONON, S.; TURNER, R.; ULIAN, T. World checklist of useful plant species. Kew: Royal Botanic Gardens, 2020.

DORIA, J. Generalidades sobre las semillas: su producción, conservación y almacenamiento. Cultivos Tropicales, v. 31, n. 1, p. 74-85, 2010.

FERREIRA, D. F. Sisvar: a computer statistical analysis system. Ciência e Agrotecnologia, v. 35, n. 6, p. 10391042, 2011.

FLORA DO BRASIL. Jardim Botânico do Rio de Janeiro. 2021. Available at: http://floradobrasil.jbrj.gov.br/. Access on: 09 Apr. 2021.

FRANÇA NETO, J. B.; KRZYZANOWSKI, F. C.; COSTA, N. P. O teste de tetrazólio em sementes de soja. Londrina: Embrapa-CNPSo, 1998.

GALE, S. W.; FISCHER, G. A.; CRIBB, P. J.; FAY, M. F. Orchid conservation: bridging the gap between science and practice. Botanical Journal of the Linnean Society, v. 186, n. 4, p. 425-434, 2018. 
HOSOMI, S. T.; CUSTÓDIO, C. C.; SEATON, P. T.; MARKS, T. R. Improved assessment of viability and germination of Cattleya (Orchidaceae) seeds following storage. In Vitro Cellular and Developmental BiologyPlant, v. 48, n. 1, p. 127-136, 2012.

HOSOMI, S. T.; SANTOS, R. B.; CUSTÓDIO, C. C.; SEATON, P. T. Pre-conditioning Cattleya seeds to improve the efficacy of the tetrazolium test for viability. Seed Science and Technology, v. 39, n. 1, p. 178-189, 2011.

HOSOMI, S. T.; SOUZA, T. B.; CUSTÓDIO, C. C.; MACHADO-NETO, N. B. Refining the tetrazolium test for evaluation of Cattleya labiata and C. tigrina seeds viability. Australian Journal of Crop Science, v. 11, n. 10, p. 1320-1326, 2017.

LALLANA, V.H.; GARCIA, L. F. Efecto de pretratamientos en la prueba de viabilidad de semillas de Trichocentrum jonesianum (Orchidaceae). Investigación Agraria, v. 15, n. 2, p. 129-132, 2013.

MACEDO, M. C.; ROSA, D. B. C. J.; SOARES, J. S.; TATARA, M. B.; HOFMMANN, N. T. K.; ROSA, Y. B. C. J. Armazenamento de sementes e aclimatização de Brassavola tuberculata Hook. Semina: Ciências Agrárias, v. 35, n. 6, p. 2883-2894, 2014.

MARCOS FILHO, J. Seed vigor testing: an overview of the past, present and future perspective. Scientia Agricola, v. 72, n. 4, p. 363-374, 2015.

MENDONÇA, R. C.; FELFILI, J. M.; WALTER, B. M. T.; SILVA JÚNIOR, M. C.; REZENDE, A. V.; FILGUEIRAS, T. S.; NOGUEIRA, P. E.; FAGG, C. W. Flora vascular do bioma Cerrado: checklist com 12.356 espécies. In: SANO, S. M.; ALMEIDA, S. P.; RIBEIRO, J. F. (ed.). Cerrado: ecologia e flora. Brasília, DF: Embrapa Informação Tecnológica, 2008. p. 422-442.

MERCADO, S. A. S.; CALEÑO, J. D. Q.; ROZO, L. Y. M. Improvement of the methodology of the tetrazolium test using different pretreatments in seeds of the genus Epidendrum (Orchidaceae). Journal of Seed Science, v. 42, e202042013, 2020.

MURASHIGE, T.; SKOOG, F. A. A revised medium for rapid growth and bioassays with tobacco tissue culture. Physiology Plantarum, v. 15, n. 3, p. 473-497, 1962.
OLIVEIRA, L. M.; CARVALHO, M. L. M.; DAVIDE, A. C. Teste de tetrazólio para avaliação de sementes de Peltophorum dubium (Sprengel) Taubert - Leguminosae Caesalpinioideae. Cerne, v. 11, n. 2, p. 159-166, 2005.

PORTE, L. F.; SANTIN, S. M. O.; CHIAVELLI, L. U. R.; SILVA, C. C.; FARIA, T. J.; FARIA, R. T.; CARVALHO, J. E.; POMINI, A. M. Bioguided identification of antifungal and antiproliferative compounds from the Brazilian orchid Miltonia flavescens Lindl. Journal of Biosciences, v. 69, n. 1-2, p. 46-52, 2014.

ROSA, Y. B. C. J.; MARQUES JÚNIOR, G. A.; SOARES, J. S.; ROSA, D. B. C. J.; MACEDO, M. C.; CEZAR, A. M. A. Estudo da viabilidade de sementes de Brassavola tuberculata Hook. em função do período de armazenamento, tempo de cultivo e tratamento pré-germinativo. Revista Brasileira de Horticultura Ornamental, v. 19, n. 2, p. 155-160, 2013.

SALAZAR, S. A.; GÉLVEZ, J. D. Determining the viability of orchid seeds using the tetrazolio and carmín índigo tests. Revista de Ciências, v. 19 n. 2, p. 59-69, 2015.

SEATON, P. T.; HOSOMI, S. T.; CUSTÓDIO, C. C.; MARKS, T. R.; MACHADO-NETO, N. B.; PRITCHARD, H. W. Orchid seed and pollen: a toolkit for long-term storage, viability assessment and conservation. In: LEE, Y.; YEUNG, E. C. (ed.). Orchid propagation: from laboratories to greenhouses: methods and protocols. New York: Humana, 2018. p. 71-98.

SOARES, J. S.; ROSA, Y. B. C. J.; TATARA, M. B.; SORGATO, J. C.; LEMES, C. S. R. Identificação da viabilidade de sementes de orquídeas pelo teste de tetrazólio. Semina: Ciências Agrárias, v. 35, n. 5, p. $2275-$ 2284, 2014.

THE PLANT LIST: a working list of all plant species. 2020. Available at: www.theplantlist.org. Access on: 05 Apr. 2020.

YANG, F. S.; SUN, A. H.; ZHU, J.; DOWNING, X. Q. S.; LIU, H. Impacts of host trees and sowing conditions on germination success and a simple ex situ approach to generate symbiotic seedlings of a rare epiphytic orchid endemic to Hainan Island, China. The Botanical Review, v. 83, n. 1, p. 74-86, 2017. 